\title{
FORMATION OF FINANCIAL SECURITY OF THE ENTERPRISE BASED ON STRATEGIC PLANNING
}

\author{
Nadiya RUSHCHYSHYN ${ }^{1}$ \\ Lviv University of Trade and Economics, Ukraine \\ Uliana NIKONENKO' \\ Ukrainian Academy of Printing, Ukraine \\ Zoryana KOSTAK ${ }^{3}$ \\ Lviv University of Trade and Economics, Ukraine
}

\begin{abstract}
The purpose of the study is to improve ways of forming financial security of the enterprise based on strategic planning. The subject of the research: formation of financial security of the enterprise on the basis of strategic planning. The methodological background of the research is a set of theoretical and general scientific methods: analysis and synthesis, theoretical and logical generalization, grouping, abstraction, and others. The paper provides a general description of the core approaches defining the concept of "financial security of the enterprise". Functional goals of financial security of the enterprise are outlined, namely: ensuring financial stability and independence; achievement of high competitiveness in the market of goods, works, services; ensuring high efficiency of financial and economic activity; ensuring high liquidity of assets, and increasing the market value of the enterprise; support for the appropriate level of business activity and image; formation of information security and commercial secrets; efficient organization of security of share capital and assets of the enterprise. The scheme of organization of financial security organization is considered based on strategic planning. It is determined that the strategic planning results in strategic plan (strategy) for ensuring the financial security of the enterprise. Such a strategy should be consistent with both financial and the company's overall strategies, as well as main goals and objectives. For the most effective implementation of the chosen financial security strategy at the enterprise, it is expedient to develop and implement a system of plans covering all aspects of the strategic planning process, including the target program, strategic, tactical, calendar, and individual plans. The system of plans should specify: the purpose of changes in the functioning of internal systems of the enterprise; terms of making changes; the work that needs to be done to make changes; their performers; necessary material, labour, and investment resources. When ensuring the financial security of the company, a special attention should be paid to the innovative development of the enterprise. The basis for the innovative development of an enterprise is the innovation potential, its formation and utilization in innovation activity. The algorithm of the strategic tasks ensuring the innovative financial security of the enterprise is proposed. The correlation between financial security and innovative development of the enterprise is explored, which is dual in nature, where both phenomena serve as the purpose of the enterprise and means of its achievement. Conclusions. Strategic planning at the enterprise, which is the basis for ensuring its financial security, will facilitate the creation of all opportunities for further financial and economic activity with positive results. At the same time, strategic planning should be based on the use of a number of measures: increase of the innovative and intellectual potential of the enterprise; use of advanced international experience in the management of material, labour, and financial resources of the enterprise; raising the skills of employees, etc. Further research should be aimed at developing and implementing an effective innovation policy that can provide long-term competitiveness of domestic enterprises and increase their financial security.
\end{abstract}

Key words: enterprise, financial security of enterprise, strategic planning, innovative development of enterprise.

JEL Classification: D21, J28, M21

\footnotetext{
Corresponding author:

${ }^{1}$ Department of Financial and Economic Security and Banking Business, Lviv University of Trade and Economics.

E-mail: nadiya r@i.ua

${ }^{2}$ Department of Financial and Economic Security, Accounting and Taxation, Ukrainian Academy of Printing.

E-mail: Uliana-nikonenko@ukr.net

${ }^{3}$ Department of Financial and Economic Security and Banking Business, Lviv University of Trade and Economics.

E-mail:kostakz@ukr.net
} 


\section{Introduction}

Successful business activity depends to a large extent on the positive results of their activities, which cannot be achieved without proper financial security. It is the latter, in the changing conditions of the external and internal environment, serves as the background for the stable activity of enterprises, providing them with sufficient financial independence and allows them to withstand real and potential risks and threats. In view of the above, the chosen topic is relevant and requires further research in the direction of activating the role of strategic planning of business entities in shaping their financial security.

The purpose of the paper is to improve the instruments ensuring the financial security of the enterprise based on strategic planning.

To achieve the goal of research, the following tasks are set and fulfilled: to examine the economic essence of the notion "financial security of the enterprise"; to define the main functional goals ensuring the financial security of the enterprise; outline the sequence of activities in the process of organizing the financial security of the enterprise; to explore the correlation between financial security and innovative development of the enterprise; to propose an algorithm for the implementation of the strategic tasks of innovative financial security.

The paper uses theoretical and general scientific methods of research: analysis and synthesis, generalization and abstraction, and others.

\section{The economic essence of the concept of "financial security of the enterprise"}

In modern economic conditions, characterized by a lack of financial resources of enterprises and organizations and the weakening of their liquidity, the intensification of competition between domestic enterprises for the markets of their products, reducing the purchasing power of the population due to the presence of inflationary processes, etc., both among scientists and managers of domestic enterprises raise their attention to ensure an effective system of financial security of the enterprise. We believe that a key role in its formation should be given to strategic planning, which in the long run will ensure a sustainable process of enterprise development on an efficient and stable basis.

In the domestic scientific literature, the financial security of the enterprise is considered as the dominant component of the economic security, on which depends the effective financial and economic activity of the business entity.

K. Goryacheva believes that "financial security is a financial condition characterized by, firstly, the balance and quality of the combining financial instruments, technologies and services used by the enterprise, and secondly, the resilience to external and internal threats, third, the ability of the financial system of the enterprise to ensure the realization of its financial interests, goals and objectives with sufficient amounts of financial resources" (Goryacheva, 2004).

According to Lavrov Y.V., "the essence of financial security of enterprises is the ability to independently develop and implement a financial strategy in accordance with the objectives of the overall corporate strategy, in an uncertain and competitive environment" (Lavrova, 2010). From the standpoint of T. B. Kuzenko, "financial security can be defined as the state of the most efficient use of information, financial indicators, liquidity and solvency, return on capital, within its limits" (Kuzenko, 2013).

We can also agree with the scientists (Buryak P., Chalapko L. (2014), Koknayeva O. (2013)) who believe that financial security represents a state of the enterprise that allows ensuring financial equilibrium, stability, solvency, and liquidity of the enterprise in the long run; satisfies the needs of the enterprise in financial resources for the sustainable expansion; ensures sufficient financial independence; allows resisting existing and emerging dangers and threats that can cause financial damage to the enterprise, or undesirable change in the structure of capital, or forcing the company to liquidate; provides sufficient flexibility when making financial decisions; ensures the protection of the financial interests of the shareholders.

In our view, the most thorough definition of financial security leads I. Blank: "The financial security of an enterprise is a quantitatively and qualitatively determined level of its financial status, which ensures the stable protection of its priority balanced financial interests from identified real and potential threats of external and internal character, parameters, which are determined on the basis of the financial philosophy and create the necessary conditions for financial support for its steady growth in the current and prospective periods. Therefore, the financial security of the enterprise is a dynamic feature of financial condition, which reflects its resilience to internal and external threats, the ability to sustainable and balanced development and to protect their financial interests" (Blank, 2004).

A generalized description of the main approaches to the definition of the essence of the "financial security of the enterprise" concept in the scientific literature is presented in Table 1.

\section{The process of financial security of the enterprise organization}

The main functional objectives of financial security of the enterprise organization should be:

- ensuring financial stability and independence;

- ensuring high efficiency of financial and economic activity;

- achievement of high competitiveness in the market of goods, works, services; 
Vol. 3, No. 4, 2017

Table 1

Interpretation of the notion "financial security of the enterprise" in the scientific literature

\begin{tabular}{|l|c|l|}
\hline \multicolumn{1}{|c|}{ Author } & Year & \multicolumn{1}{c|}{ Definition } \\
\hline Arafeev V. & 2010 & $\begin{array}{l}\text { The financial security of the enterprise is protection against possible financial losses and prevention of } \\
\text { bankruptcy of the enterprise, achievement of the most effective use of corporate resources. }\end{array}$ \\
\hline $\begin{array}{l}\text { Buryak P., } \\
\text { Chalapko L. }\end{array}$ & 2014 & $\begin{array}{l}\text { Financial security represents a state, in which the company: is in a financial equilibrium, provides } \\
\text { stability, solvency, and its liquidity in the long-term period; satisfies the need for financial resources } \\
\text { for the sustained, extended reproduction; provides sufficient financial independence and protection of } \\
\text { financial interests of the owners of the enterprise. }\end{array}$ \\
\hline Koknaeva O. & 2013 & $\begin{array}{l}\text { Financial security defines the boundary condition of financial stability, which should be an enterprise } \\
\text { for the implementation of its strategy, characterized by the ability of the company to withstand internal } \\
\text { and external threats. }\end{array}$ \\
\hline Kuzenko T. & $\begin{array}{l}\text { Financial security is a state of the enterprise, which: 1) provides for financial equilibrium, stability, } \\
\text { solvency, and liquidity in the long run; 2) ensure sufficient financial independence; satisfies the } \\
\text { needs of the enterprise in financial resources for the sustained, expanded reproduction; 3) is able to } \\
\text { withstand the existing and emerging dangers that seek to cause financial harm to the enterprise or } \\
\text { to change in spite of the desire of the structure of own capital, or to forcibly liquidate an enterprise; } \\
\text { 4) provides sufficient flexibility in making financial decisions. }\end{array}$ \\
\hline $\begin{array}{l}\text { Kovalchuk N., } \\
\text { Korbutiak A. }\end{array}$ & $\begin{array}{l}\text { Financial security - the state of the most effective use of corporate resources of the enterprise, } \\
\text { expressed in the best value of financial indicators of profitability and profitability of the business, } \\
\text { quality of management, use. }\end{array}$ \\
\hline
\end{tabular}

Source: compiled by the authors based on (Arefiev V. (2010), Buryak, P., Chalapko L.( 2014), Kuzenko T., Poltinina O. (2013), Kovalchuk N., Korbutiak A. (2014))

- ensuring high liquidity of assets and raising the market value of the enterprise;

- support for the appropriate level of business activity and image;

- formation of information security and business secrets; - effective organization of security of own capital and property of the enterprise.
The main functional objectives predetermine the separation of the necessary structural elements and the general scheme of financial security of the enterprise organization. The general scheme of the organization of financial security process covers the following measures, carried out consistently or simultaneously (Fig. 1).

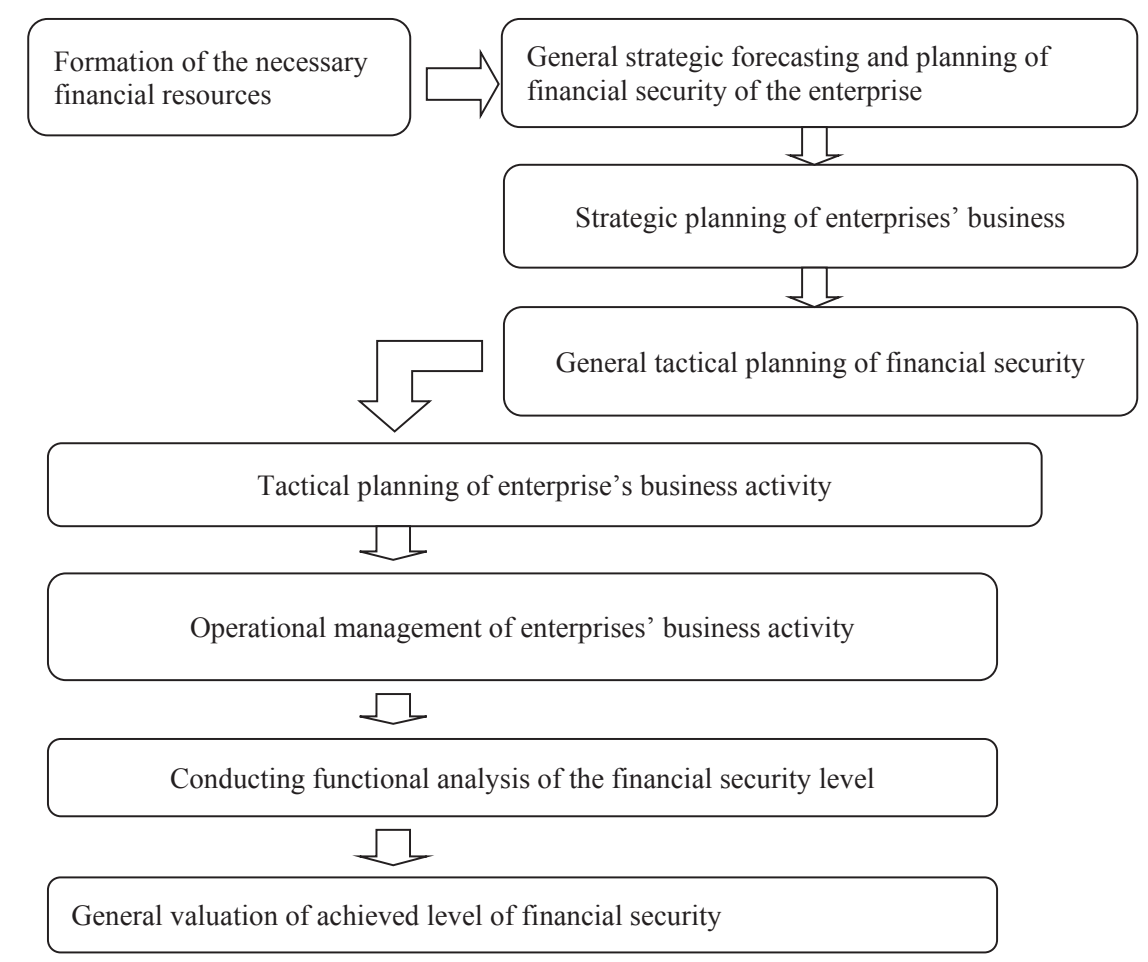

Fig. 1. The general scheme of the process of financial security of the enterprise organization based on strategic planning

Source: (Buryak P., Chalapko L. (2014)) 
The result of strategic planning is a strategic plan (strategy) to ensure the financial security of the enterprise. Such a strategy should be consistent with both the financial strategy and the overall strategy of the enterprise, to meet their goals and objectives. The strategy of ensuring the financial security of an enterprise should be considered as a model required for achieving certain goals within the framework of the corporate and financial strategy by coordinating, distributing and using financial resources of the enterprise in order to ensure an adequate level of financial security of the enterprise.

The strategy defines the component (part) of the corporate mission and its objectives relating to financial security, results of the analysis of the internal and external financial environment, qualitative and quantitative parameters of the use of financial resources that meet the requirements of ensuring an adequate level of financial security, responsible for the implementation of the planned measures, the amount and sources of financial resources (budget) needed to ensure the financial security of the enterprise.
When implementing the process of organization of financial security of an enterprise based on strategic planning, it is required to consider the following most important factors:

- the level of financial security and its characteristics;

- the state of the life cycle of the enterprise development; - risks and threats within the internal and external environment and their changes;

- financial and economic opportunities of the enterprise; - market conditions;

- modification of actions of subjects of the institutional environment in trade, etc.

It should be noted that the configuration of policy measures to ensure the financial security of an enterprise is determined by the presence and features of external and internal threats to its activities. Only due protection against negative factors and threats creates preconditions for increasing the efficiency of resource utilization and financial and economic activities in general. In this aspect, it is also important to monitor factors that pose a threat to financial security, since it is the basis for

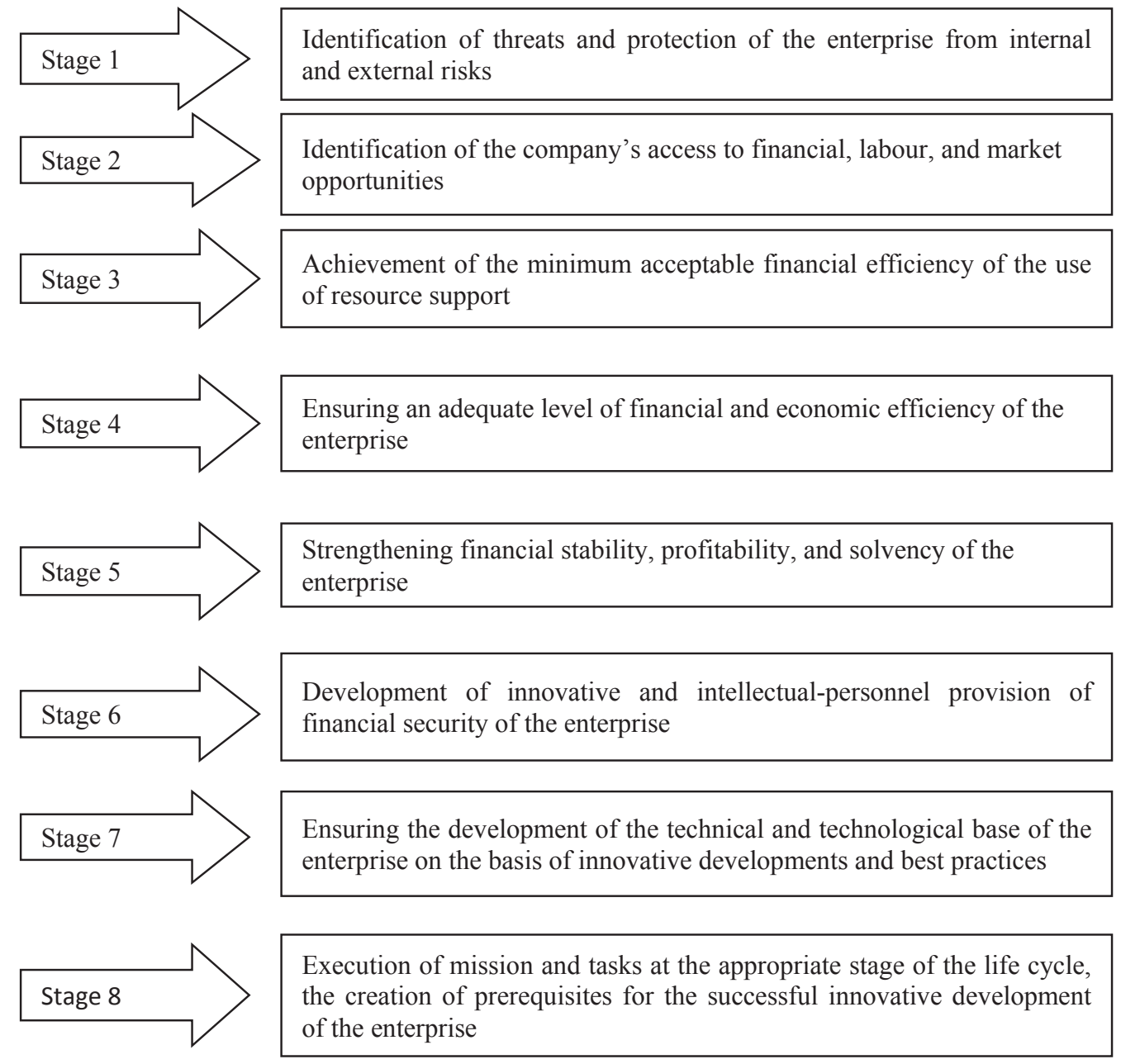

Fig. 2. The algorithm of tasks of the strategy of innovative financial security of the enterprise Source: developed by the authors 
its implementation. Monitoring should become an important component of short- and mediumterm forecasting and development of a strategy for strengthening the financial security of the enterprise within the framework of its economic development policy (Koknayeva, 2013).

Competitive position, as well as the innovative potential of the enterprise, impact the choice of strategy for strengthening financial security. After all, the ability to function is stably achieved at the expense of competitive advantages, that is, a set of innovative factors and parameters that ensure the identification and selection of the company from the total number of competitors and enable the ability to successfully develop in modern conditions.

In order to successfully implement the strategy of innovative financial security of the enterprise, one must adhere to a clear algorithm of action, which is proposed in Fig. 2.

Proposed in Fig. 2 set of measures reflects not only the sequence of tasks' implementation within the framework of the implementation of innovative financial security strategy but also determines the hierarchy of their importance (priority). The most important point in shaping the strategy of innovative financial security of the enterprise is to analyse the real and potential threats to the macro and micro environment.

Macro threats - high inflation in the country; low purchasing power of the population; unfavourable investment climate; imperfection of economic legislation, its instability; high level of tax rates; fluctuations in exchange rates, etc., and threats to the micro-environment may include threats from thirdparty suppliers of products, competitors, consumers, state and local authorities, etc.

In order to prevent negative consequences in the form of threats to financial security, enterprises should consider in advance about the choice of measures and methods that will ensure the detection of a risky situation and will enable the elimination of its causes at the very beginning. In our opinion, for domestic enterprises, the most effective methods of managing risks and threats are their minimization, insurance, and diversification.

\section{An innovative component in the formation of financial security of the enterprise}

When forming the financial security of the company, a particular attention should be paid to the innovative development of the enterprise. The basis of innovation development of an enterprise is the innovation potential, its formation and use in innovation activity. Based on the balance sheet principle, three key components of the innovative development of the enterprise can be distinguished: financial, material, and intellectual, which are in cyclic interconnection and interdependence. The same components are projected onto the innovative development potential of an enterprise and provide it with effective development in the current and long-term periods.

The connection between financial security and the innovative development of the enterprise is dual in nature, where both phenomena serve as the purpose of the enterprise and the means of its achievement. Financial security, on the one hand, is a necessary prerequisite and a definite reflection of the innovative development potential since its processes are aimed at ensuring development processes. On the other hand, the process of innovation development of the enterprise should be directed, in particular, to the formation and functioning of systems for the provision of its financial security (Voloschuk, 2014).

Currently, the majority of domestic enterprises are experiencing a complete stagnation in innovation activities. The number of enterprises that innovate every year is shrinking. This situation is a confirmation that in the innovation sector, the main source of financing innovative activity is the own funds of economic entities, which, for the most part, lack such a long-term and risky activity (Kostak, 2016). The dynamics of the main indicators of innovation activity in Ukraine is reflected in Table 2.

Data represented in Table 2 indicate that in 2012-2016, a significant reduction in the number of employees involved in the implementation of scientific research (in 66,428 people) was observed in Ukraine. Simultaneously, there was a decrease in internal costs for fundamental research and development - by 389 , 6 million UAH and a reduction in the number of

Table 2

Dynamics of the main indicators of innovation activity in Ukraine for 2012-2016

\begin{tabular}{|l|c|c|c|c|c|c|}
\hline \multicolumn{1}{|c|}{ Indicator } & 2012 & 2013 & 2014 & 2015 & $2016^{*}$ & $\begin{array}{c}\text { Deviation }(+,-) \\
2016 / 2012\end{array}$ \\
\hline $\begin{array}{l}\text { The number of employees involved in the research, } \\
\text { individuals }\end{array}$ & 164340 & 155386 & 136123 & 122504 & 97912 & -66428 \\
\hline $\begin{array}{l}\text { Internal costs for basic research and development, } \\
\text { million UAH }\end{array}$ & 2615,3 & 2698,2 & 2452,0 & 2460,2 & 2225,7 & $-389,6$ \\
\hline Introduction of innovative types of products, names & 3403 & 3138 & 3661 & 3136 & - & - \\
\hline Introduction of new technological processes, quantity & 188 & 1576 & 1743 & 1217 & - & - \\
\hline
\end{tabular}

* Starting from 2015, frequency of the state statistical observation "Innovative activity of enterprises" has been changed from "annual" to "biennial"

Source: statistical Yearbook (2017) 
innovative types of products, indicating a low innovation activity of enterprises. In such a situation, managers of enterprises need to focus on the innovative components of the strategic development of the enterprise, pay much attention to the innovative upgrade of the material and technical base, use the international experience of management of intellectual resources, and attract highly skilled workers in the field of IT technologies.

For the most effective implementation of the chosen financial security strategy at enterprises, it is expedient to develop and implement a system of plans covering all aspects of the strategic planning process, including the target program, strategic, tactical, calendar, and individual plans. The system of plans should specify: the purpose of changes in the functioning of internal systems of the enterprise; terms of making changes; the work that needs to be done to make changes; their performers; necessary material, labour, and investment resources. In each strategic plan, it is necessary to determine the timing and nature of the measures aimed at achieving the goal. This document should include a number of elements: the overall strategy of the enterprise; action plan for creating competitive advantages; assumptions about the development trends and the nature of competition; changes in the environment; analysis of strengths and weaknesses of the enterprise; mission and goals; functional strategies and strategies in case of force majeure; resources needed to implement the strategy; assessment of the probability of strategic success; schedule of major events (Buryak, Chalapko, 2014).

\section{Conclusions from the conducted research and perspectives.}

Summarizing the above, it should be emphasized that strategic planning at the enterprise, which is the basis for ensuring its financial security, will facilitate the creation of all opportunities for further financial and economic activity with positive results. At the same time, strategic planning should be based on the use of a number of measures: increase of the innovative and intellectual potential of the enterprise; introduction of advanced international experience in the management of material, labour, and financial resources of the enterprise; raising the skills of employees of the enterprise, etc.

Further research should be aimed at developing and implementing an effective innovation policy that can provide long-term competitiveness of domestic enterprises and increase their financial security.

\section{References:}

Arefiev, V. (2010). The strategy of providing financial security of the enterprise as a guarantee of its effective and stable functioning. Bulletin of the Economy of Transport and Industry, No. 29, p. 65-68.

Buryak, P., Chalapko, L. (2014). Financial Planning in Providing Financial Security at Enterprises. Scientific Bulletin of Kherson State University, Issue 9-1, Part 3: 112-115.

Blank, I. (2004). Management of financial security of the enterprise - Kiev, Elga, Nika-Center, 784 p.

Voloschuk, L. (2014). Economic Security and Innovative Development of an Industrial Enterprise: The Essence and Interconnection as Objects of Management. Economics: Realities of Time, No. 6 (16), p. 217-223.

Goryacheva, K. (2004). Estimating the level of financial security of the enterprise. Retrieved from: http://dspace.uabs.edu.ua/jspui/bitstream/123456789/3159/1/Gorjacheva.pdf

Lavrova, Yu. (2010). The mechanism of financial security of the enterprise. Bulletin of economy of transport and industry, No. 29, p. 127-130.

Kuzenko, T. Poltinina, O. (2013). Formation of the system of providing financial security of subjects of entrepreneurship on the basis of controlling. Problems of the economy, No.1, p. 345-352.

Koknayeva, O. (2013). Peculiarities of the Methodological Toolkit for the Study of the Financial-Economic Security of Trade Enterprises. Retrieved from: http: // www pokaznyk_ocinky_.pdf.

Kovalchuk, N. Korbutiak, A. (2014). Approaches to assess the financial and economic security of domestic enterprises. Business-inform, No. 10, p. 249-255.

Kostak, Z. (2016). The role of financial and economic security in the strategic development of entrepreneurial structures. Visnyk of Lviv Trade and Economic University, Issue 51, p. 149-155.

Statistical Yearbook (2016). Scientific and innovative activity in Ukraine. Retrieved from http://www.cisstat.com/ innovation/Ukraine_publication_01.pdf.

Надежда РУЩИШИН, Уляна НИКОНЕНКО, Зоряна КОСТАК

ФОРМИРОВАНИЕ ФИНАНСОВОЙ БЕЗОПАСНОСТИ ПРЕДПРИЯТИЯ НА ОСНОВЕ СТРАТЕГИЧЕСКОГО ПЛАНИРОВАНИЯ

Аннотация. Целью исследования является совершенствование путей формирования финансовой безопасности предприятия на основе стратегического планирования. Предмет исследования: формирование финансовой безопасности предприятия на основе стратегического планирования. Методологической основой исследования является совокупность теоретических и общенаучных методов: анализ и синтез, 
Vol. 3, No. 4, 2017

обобщение, абстрагирование и другие. В работе представлено обобщенную характеристику главным подходам к определению сущности понятия «финансовая безопасность предприятия». Определены функциональные цели экономической безопасности предприятия, а именно: обеспечение финансовой устойчивости и независимости; достижения высокой конкурентоспособности на рынке товаров, работ, услуг; обеспечение высокой эффективности финансово-хозяйственной деятельности; обеспечение высокой ликвидности активов и повышение рыночной стоимости предприятия; поддержка соответствующего уровня деловой активности и имиджа; формирование информационной безопасности и коммерческой тайны; эффективная организация безопасности собственного капитала и имущества предприятия. Рассмотрена схема процесса организации экономической безопасности предприятия на основе стратегического планирования. Определено, что результатом стратегического планирования является стратегический план (стратегия) обеспечение финансовой безопасности предприятия. Такая стратегия должна отвечать как финансовой стратегии, так и общей стратегии предприятия, соответствовать их целям и задачам. С целью наиболее эффективной реализации выбранной стратегии финансовой безопасности на предприятии целесообразно разработать и внедрить систему планов, охватывающихвсе аспекты процесса стратегического планирования, включая целевую программу, стратегические, тактические, календарные и индивидуальные планы. В системе планов должны указываться: цель изменений в функционировании внутренних систем предприятия; сроки внесения изменений; работы, которые необходимо осуществить для внесения изменений; их исполнители; необходимые материальные, трудовые и инвестиционные ресурсы. При формировании финансовой безопасности предприятия особое внимание следует уделить инновационному развитию предприятия. Основой инновационного развития предприятия является инновационный потенциал, его формирования и использования в инновационной деятельности. Предложен алгоритм выполнения задач стратегии инновационного обеспечения экономической безопасности предприятия. Исследована связь между финансовой безопасностью и инновационным развитием предприятия, имеет дуальный характер, где оба явления выступают в качестве цели предприятия и средства ее достижения. Выводы. Стратегическое планирование на предприятии, которое является основой в процессе обеспечения его финансовой безопасности, должно способствовать созданию всех возможностей для дальнейшей финансово-хозяйственной деятельности с положительными результатами. В то же время стратегическое планирование должно базироваться на использовании ряда мер: повышение инновационного и интеллектуального потенциала предприятия; использование передового международного опыта в области управления материальными, трудовыми и финансовыми ресурсами предприятия; повышение квалификации работников предприятий и тому подобное. Дальнейшие исследования должны быть направлены на разработку и внедрение действенной инновационной политики, способной обеспечить долгосрочную конкурентоспособность отечественных предприятий и повысить их финансовую безопасность. 